weighed against those of chemoprophylaxis. Mayon-White has recently compiled the evidence and produced a coherent policy for using pneumococcal vaccine; his proposed indications are patients aged 55-70 with diabetes or chronic disease of the heart, lung, or liver and those aged 2-70 years with chronic renal disease, sickle cell disease, or asplenia. ${ }^{22}$ Only its usefulness in patients with chronic lung disease could be questioned. ${ }^{16}$

The vaccine does not deserve to be ignored, and the cautious start advocated by Mayon-White is overdue. Official guidance would be helpful, but none of the polysaccharide vaccines is mentioned in the useful guide to vaccines now available from the Department of Health. ${ }^{23}$

NORMAN D NOAH

Consultant Epidemiologist,

Communicable Disease Surveillance Centre,

London NW9 5EQ

I Mufson MA. Pncumociccal infections. F.A.11 1981:246:1942-8.

2 MacFarlane JT, Ward MJ, Finch RG, Macrac AD. Hospital study of adult community-acquired pneumonia. Lancet 1982;ii:255-8.

White RJ, Blainey AD, Harrison KJ, Clarke SKR. Causes of pneumonia presenting to a distric general hospital. Thorax 1981;36:566-70.
4 Holmberg H. Aetiology of community-acquired pneumonia in hospital treated patients. Scand $\mathcal{f}$ Infect Dis 1987;19:491-501.

5 Young SEJ. Bacteraemia 1975-1980: a survey of cases reported to the PHLS Communicable Disease Surveillance Centre. $\mathcal{F}$ Infect 1982;5:19-266.

6 Noah ND. Epidemiology of bacterial meningitis: UK and USA. In: Williams JD, Burnie J, eds. Bacterial meningitis. London: Academic, 1987:93-115.

Feldman C, Kallenbach JM, Miller SD, Thorburn JR, Koornhof HJ. Community-acquired pneumonia due to penicillin-resistant pneumococci. $N$ Engl f Med 1985;313:615-7.

Paton JH, Reeves DS. First multiresistant pneumococcus in Britain. Br Med f 1987;295:810-1.

9 Sacho H, Klugman KP, Koornhof HJ, Ruff P. Community-acquired pneumonia in an adult due to a multiply-resistant pneumococcus. F Infect 1987; 14:188-9.

10 Austrian RA. A reassessment of pneumococcal vaccine. $N$ Engl f Med 1984;310:651-3.

11 Clemens JD, Shapiro ED. Resolving the pneumococcal vaccine controversy: Are there alternatives to randomized clinical trials? Rev Infect Dis 1984;6:589-600.

2 Bolan G, Broome CV, Facklam RR, Plikaytis BD, Fraser DW, Schlech WF. Pneumococcal vaccine efficacy in selected populations in the United States. Ann Intern Med 1986;104:1-6.

3 Anonymous. Splenectomy - a long-term risk of infection [Editorial]. Lancet 1985;ii:928-9.

13 Anonymous. Splenectomy - a long-term risk of infection [Editorial]. Lancet 1985;11:928-9. among immunised and splenectomised patients in Israel. F Infect 1985;10:38-42.

15 Colman G, Hallas G. Systemic disease caused by pneumococci. I Infect 1983;7:248-55.

6 Williams JH, Moser KM. Pneumococcal vaccine and patients with chronic lung disease. Ann Intern Med 1986;104: 106-9.

17 Broome CV, Facklam RR, Fraser DW. Pneumococcal disease after pneumococcal vaccination. An alternative method to estimate the efficacy of pneumococcal vaccine. N Engl f Med 1980;303: 549-52.

18 Fedson DS, Baldwin JA. Previous hospital care as a risk factor for pneumonia. Implications for immunization with pneumococcal vaccine. $\mathcal{F} A M A$ 1982;248:1989-95.

19 Woodhead M, Macfarlane JT. Prevention of pneumococcal pneumonia. Lancet 1983;i:1044.

20 Fedson DS. Hospital care and pneumococcal immunisation policy. Lancet 1982;ii:1226.

21 LaForce FM, Eickhoff TC. Pneumococcal vaccine: an emerging consensus. Ann Intern Med LaForce FM, Eick
1988;108:757-9.

22 Mayon-White RT. Pneumococcal vaccine. Thorax 1988;43:345-8

23 Joint Committee on Vaccination and Immunisation. Immunisation against infectious disease London: HMSO, 1988.

\title{
The roots of violence
}

\section{No easily identified causes}

Violence once again commands the news headlines. But violence may mean so many things: the riots of the deprived inner cities, rural rowdyism in small country towns, or the vulgar patriotism of English football fans away from home. Or violence may be implanted in the home as child abuse, or it may be sexual assaults, racial attacks, purse snatches, bank robberies, terrorism, or warfare. There is also much death and injury on the roads, although curiously we do not think of this as violence. Obviously such a widely expressed human difficulty can have no single cause.

It is a common medical practice before attempting a diagnosis to take a history. According to popular wisdom, Britain's pulse is racing with an acute disorder - something with an onset "20 or 30 years ago" or "since the war," a symptom of "permissiveness," moral decline, the break up of family life, and weakened respect for authority. But actual history does not support this nostalgic perception. The interwar years already knew these same complaints, and people were as convinced as people are today that they faced a new problem with crime and violence. And both the problem and the complaint were already well rehearsed in late Victorian and Edwardian England. ' The word "hooliganism" is of Victorian origin and described violent gangs of youths who fought pitched battles among themselves and with the police in the late 1890s in the slums of London.

Another timeless complaint condemns alcohol as the cause of violence, but it does not explain even a limited form of violence such as football hooliganism. ${ }^{2}$ Unemployment is also seen as a cause of violence, but, although there are established links between unemployment and other difficulties such as ill health, drug misuse, and the size of the prison population, ${ }^{3-8}$ unemployment cannot in itself account for violence. Indeed, another view is that "affluence" causes violent misbehaviour: this argument has been advanced not only against the "rural rowdies" of the 1980s but also against the teddy boys of the 1950s; and even Queen Victoria's original hooligans were blamed in some quarters on "too much pocket money."
The search for causes of violence has frustrated social scientists, and criminologists have turned away from a preoccupation with what makes offenders "tick" towards a concern with the victims of crime. ${ }^{9}$ If crime cannot be easily curbed then it may be better to study how its effects might be ameliorated by looking at what it does to victims and communities.

Victim surveys, such as the British crime survey conducted by the Home Office Research and Planning Unit, have already laid several myths about crime and violence. ${ }^{1011}$ It is often imagined, for example, that the elderly are the most likely victims of personal violence, but the most likely victims are in fact men under 29, particularly if they go out regularly in the evenings. Nor is this simply because the elderly spend less time out of doors: even when activity rates are controlled the elderly are significantly less at risk of a range of violent crimes. ${ }^{12}$ Nevertheless, the fear of crime remains extremely high among the elderly, suggesting that better public education and reassurance are required.

Another striking finding from the British crime survey is that crime is more of a problem for the most disadvantaged sections of the population. "It is the poorest council estates and racially mixed areas that suffer most crime and violence. Robin Hood theories of crime simply will not wash. Finally, all measures of violence - whether official crime statistics or victim surveys - seriously underestimate domestic violence, whether against women or children. Women are probably more likely to be the victims of assault than men if domestic violence is included, but this is often not the case..$^{13}$

Doctors are not the leading agency for dealing with victims of crime, and they might do best to refer victims to a local victim support group. In accident and emergency units, where the most serious injuries will be encountered, there is a case for staff to be available who are trained and experienced in handling complex interpersonal and domestic disputes. We have begun to learn the importance of effective interagency and interprofessional working in child abuse. The principle 
may need extending to other types of violence, although we should not forget the difficulties commonly experienced in multiagency work. ${ }^{15}$

What is needed above all is a sense of perspective and realism. Most physical harm is sustained through household accidents, industrial injuries, and road accidents. Violent crime is no more than $5 \%$ of all serious crime. That the recorded incidence of violence is on the increase may show not that society is falling apart but rather that we live in an increasingly orderly society that tolerates criminal injury far less than in the uncivilised past.

Professor of Social Work,

GEOFFREY PEARSON

Enfield, Middlesex EN3 4SF

1 Pearson G. Hooligan: a history of respectable fears. London: Macmillan, 1983.

Dunning E, Murphy P, Williams J. The roots of football hooliganism. London: Routledge, 1988. Hakim C. The social consequences of high unemployment fournal of Social Policy 1982:11:433-67. . The

British Medical Association. Deprivation and ill-health. London: BMA, 1987.

Pearson G, Gilman M, McIver S. Young people and heroin: an examination of heroin use in the north of England. London: Health Education Council, 1985.

6 Peck DF, Plant MA. Unemployment and illegal drug use. Br Med f 1986;293:929-32.

7 Parker H, Baxk K, Newcombe R. Living with heroin. Milton Keynes: Open University Press, 1988.

8 Box S. Recession, crime and punishment. London: Macmillan, 1987.

Maguire M, Pointing J, eds. Victims of crime: a new deal? Milton Keynes: Open University Press, 1988.

10 Hough M, Mayhew P. The British crime survey. London: HMSO, 1983. (Home Office Research Study No 76. .)

11 Hough M, Mayhew P. Taking account of crime: key findings from the 1984 British crime survey. London: HMSO, 1985. (Home Office Research Study No 85. .)

12 Clarke R, Ekblom P, Hough M, Mayhew P. Elderly victims of crime and exposure to risk. Howard Journal of Criminal fustice 1985;24:1-9.

13 Jones T, MacLean B. Young J. The Islington crime survev. Aldershot: Gower, 1986

13 Jones T, MacLean B. Young J. The Islington crime survey. Aldershot: Gower, 1986.

15 Blagg H, Pearson G, Sampson A, Smith D, Stubbs P. Interagency cooperation: rhetoric and reality. In: Hope T, Shaw M, eds. Communities and crime reduction. London: HMSO, 1988 204-20.

\section{Supporting victims of violent crime}

\section{Doctors should make links with victim support schemes}

More than three quarters of victims of violent crimes who attend accident and emergency departments are not recorded in the crime statistics kept by the police. ${ }^{1}$ The British crime surveys have confirmed the magnitude of unrecorded crime, ${ }^{23}$ though medical data may show more accurately the incidence of severe injury resulting from domestic and street violence. Doctors have a responsibility to help these victims of crime get the support they sometimes urgently need, and the best way may be to put them in touch with the many victim support schemes.

The British crime surveys were initiated principally because of an increasing awareness of the inadequacy of Home Office data on crime. The survey interviews one person over the age of 16 in each of 11000 randomly selected households in England and Wales and 5000 in Scotland and records crimes committed during the previous 12 months. Though the surveys depend on respondents reporting offences and therefore still tend to undercount crimes, they have shown that police crime statistics included only $23 \%$ of woundings, $11 \%$ of robberies, and $26 \%$ of sexual offences. ${ }^{3}$

The principal agencies in Britain for supporting victims of crime are the victim support schemes, which rely heavily on the police for referrals. In 1986 only $4 \%$ of schemes regularly received referrals from other sources. ${ }^{+}$The first scheme was established in Bristol in 1974, and by December 1987 there were 350 schemes. A central advisory body, the National Association of Victim Support Schemes, was formed in 1979, and in 1987 a government grant of $£ 9$ m enabled individual schemes to appoint paid coordinators. These developments, a Council of Europe recommendation, ${ }^{5}$ and a United Nations declaration $^{6}$ all reflect increasing concern for victims of crime. Though some schemes are closely associated with the probation service and the police, independence and confidentiality are highly valued.

In addition to medical treatment victims need emotional support and reassurance not available from other sources such as the family; information about compensation; help with approaches to the Criminal Injuries Compensation Board, social services, crime prevention officers, and legal advice centres; and practical help to repair or recover property after robbery. ${ }^{+}$The resources of the support schemes may not be available to victims of assault who seek treatment of physical injuries simply because there are few or no links between the schemes and either hospitals or general practices. Doctors are often ignorant of wider sources of support, and there may be little time to discuss or initiate this support as most victims are outpatients and most assaults occur late at night and at weekends. ${ }^{7}$ Accident and emergency departments and general practices should therefore forge links with victim support schemes.

Though the incidence and duration of psychiatric distress after assault and robbery is not clear, there is growing evidence that this is an important problem. ${ }^{8}$ Criminologists and psychiatrists have begun to look at the psychiatric distress that follows assault, and it seems particularly common after assaults at work and after those that result in loss of earnings. ${ }^{9}$ A recent study found that anger, difficulty in sleeping, uneasiness, confusion, fear, shivering, inability to perform ordinary tasks, and loss of interest were experienced by more than $40 \%$ of victims after robbery or assault. ${ }^{+}$Conversely, many victims clearly suffer little distress and cope well with help from family and friends. ${ }^{10}$

Some victims of assault who attend accident and emergency departments will suffer some psychiatric disorder and will need specialist assessment and care. ${ }^{911}$ The serious psychiatric sequelae of rape are well described, and psychiatric services have been developed to deal with them. Similar services should be made available to assault victims, though research is necessary to clarify how best to deliver them.

Senior Lecturer in Oral and Maxillofacial Surgery,

JONATHAN SHEPHERD

Bristol Royal Infirmary,

Bristol BS2 8HW

\footnotetext{
Shepherd JP, Pierce NX, Scully C, Leslie IJ. Rates of violent crime from hospital records. Lance 1987 ;ii: $1470-1$

2 Hough $M$. The impact of victimisation: findings from the British Crime Survey. Victimology 1983:10:488-97.

3 Hough M, Mavhew P. Taking account of crime: key findings from the 1984 British crime survey. London: HMSO, 1985. (Home Office Research Study No 85 .)

+ Maguire M, Corbett C. The effects of crime and the work of victims support schemes. Aldershot: Gower, 1987

5 European Committee on Crime Problems. The position of the victim in the framework of criminal law and procedure. Strasburg: Council of Europe, 1985.

6 United Nations General Assembly. Declaration of basic principles of justice for victims of crime. New York: United Nations Department of Public Information, 1985. (Resolution 40/34.)

7 Shepherd JP, Shapland M, Irish M, Scully C, Leslie IJ. Assault: characteristics of victims attending an inner city hospital. Injury 1988;19:185-90.

8 Raphael B, Middleton W. After the horror. Br Med f 1988;296:1142-3.

9 Shapland J, Willmore J, Duff PR. Victims in the criminal justice system. Aldershot: Gower, 1985:97108 .

10 Mayhew P. The effects of crime: victims, the public and fear. Sixteenth criminological research conference: research on victims. Strasburg: Council of Europe, 1984.

1 Hamilton JR. Violence and victims: the contribution of victimology to forensic psychiatry. Lancet 1987;i:147-50.
} 